\title{
Pengaruh Ukuran Biochar Bambu dan Dosis Pupuk Urea terhadap Efisiensi Pupuk dan Hasil Tanaman Sawi Hijau (Brassica juncea L.) pada Tanah Berpasir
}

\author{
ANAK AGUNG GDE PREHATRESNA ADI ASMARA, I WAYAN DANA ATMAJA*), \\ ANAK AGUNG NGURAH GEDE SUWASTIKA, DAN ANAK AGUNG ISTRI \\ KESUMADEWI
}

Program Studi Agroekoteknologi Fakultas Pertanian Universitas Udayana

Jl. PB Sudirman Denpasar Bali 80231

${ }^{*}$ E-mail: atmaja.dana@yahoo.com

\begin{abstract}
The Effect of Bamboo Biochar Size and Urea Fertilizer Dosage on Fertilizer Efficiency and Yield of Green Mustard (Brassica juncea L.) in Sandy Soil. Biochar is charcoal produced from incomplete combustion (carbonization). Biochar is a soil amendment agent that has long been known in agriculture which is useful for increasing soil productivity. This study aims to determine the effect of bamboo biochar size and urea fertilizer dosage on the efficiency of urea fertilizer and yield of green mustard (Brassica juncea L.). This research was conducted from May 2020 to September 2020 at the Experimental Garden of the Faculty of Agriculture, and at the Laboratory of Soil and Environmental Sciences, Faculty of Agriculture, Udayana University. The research design used was a completely randomized design (CRD) with 2 factorials and 3 replications. The treatment factors consisted of $\mathrm{P} 0=0 \mathrm{~kg}$ urea (control) $(0$ grams $/ \mathrm{pot}), \mathrm{P} 1=100 \mathrm{~kg}$ urea $/$ ha $(0.2$ grams $/$ pot $), \mathrm{P} 2=200 \mathrm{~kg}$ urea $/$ ha $(0.4$ grams $/$ pot $), \mathrm{P} 3=300 \mathrm{~kg}$ urea $/$ ha $(0.6$ gram $/$ pot), $\mathrm{B} 1=0.25-2.00 \mathrm{~mm}, \mathrm{~B} 2=2.38-2.83 \mathrm{~mm}, \mathrm{~B} 3=2.83-3.36 \mathrm{~mm}$. The parameters observed were levels of ammonium, nitrate, soil $\mathrm{pH}$, microbial population, soil respiration, crop yields including fresh weight and oven dry weight of the plant. The results of the analysis showed that the effect of biochar and urea fertilizers interacted very significantly with the parameters of the microbial population and had no significant effect on the parameters of ammonium, nitrate, soil $\mathrm{pH}$, soil respiration, plant fresh weight, plant dry weight, root fresh weight, root dry weight and efficiency. fertilizer. Biochar treatment has a significant effect on biological factors and fertilizer treatment affects soil chemical properties, crop yields are influenced by a single factor.
\end{abstract}

Keywords: Bamboo biochar, urea fertilizer, mustard greens (Brassica juncea L.) 


\section{ANAK AGUNG GDE PREHATRESNA ADI ASMARA et al. Pengaruh Ukuran Biochar...}

\section{PENDAHULUAN}

Tanaman sawi hijau (Brassica juncea

L.) merupakan salah satu komoditas tanaman hortikultura dari jenis sayur sayuran yang dimanfaatkan daun-daun yang masih muda (Pracaya, 2011). Tanaman sawi hijau beradaptasi dengan baik ditempat yang berudara panas maupun berudara dingin sehingga dapat diusahakan didaerah dataran tinggi maupun dataran rendah(Ibrahim dan Tanaiyo, 2018).Pertumbuhan tanaman sawi hijau dipengaruhi oleh faktor internal dan faktor eksternal, tanaman sawi hijau dapat tumbuh dengan baik pada tanah yang subur, gembur, mudah mengikat air dan kaya akan bahan organik(Anggraini, 2020). Keasaman tanah yang baik untuk pertumbuhan tanaman ini adalah $\mathrm{pH}$ 7. Cara untuk mendapatkan hasil tanaman yang baik adalah dengan pemupukan. Pemupukan merupakan suatu usaha penambahan unsur - unsur hara dalam tanah yang dapat meningkatkan kesuburan tanah dan mutu hasil tanaman (Istarofah dan Samalah, 2017).

Nitrogen merupakan unsur hara utama bagi pertumbuhan tanaman sebab merupakan penyusun dari semua protein dan asam nukleat. Nitrogen berperan dalam merangsang pertumbuhan vegetative, yaitu tanaman menjadi lebih hijau dan merupakan bahan penyusun klorofil daun yang penting untuk fotosintesa. Pemberian pupuk urea bila dalam jumlah yang berlebihan akan berbahaya bagi lingkungan sehingga penggunaan pupuk khususnya nitrogen harus diefisienkan (Rahmadhanidkk.,2016).

Biochar atau disebut juga arang hayati merupakan arang yang dihasilkan dari pembakaran yang tidak sempurna(karbonisasi). Biochar merupakan bahan pembenah tanah yang telah lama dikenal dalam bidang pertanian yang berguna untuk meningkatkan produktivitas tanah(Sasmita dkk., 2017).. Bahan utama untuk pembuatan biochar adalah limbah limbah sisa kerajinan dan limbah pertanian seperti bambu. Biochar digunakan sebagai pembenah tanah bersama pupuk organik dan anorganik, biochar dapat meningkatkan produktivitas, serta retensi dan ketersediaan hara bagi tanaman (Gani,2009).Tanah berpasir banyak mempunyai pori-pori makro sehingga sulit menahan air serta unsur hara, biocharberbahan baku dari limbah bambu dapat memperbaiki kualitas tanahdengancara, antara lain meningkatkan porositas, berat volume dan ketersediaan air, meningkatkan $\mathrm{pH}, \mathrm{C}$-Organik, $\mathrm{K}$, dan KTK, mengurangi pencucian N. Pengaruh 
biochar di tanah terhadap sifat biologi tanah yaitu Biochar dapat memengaruhi populasi dan aktivitas mikroorganisme tanah(Nigussie dkk., 2012).

\section{BAHAN DAN METODE}

Penelitian ini dilaksanakan mulai bulan Mei hingga bulan September 2020, penelitian ini terdiri dari 2 tahap yaitu penanaman dan analisis kandungan kimia, biologi tanah. Penanaman dilaksanakan di Kebun Percobaan Fakultas Pertanian Universitas Udayana dan analisis tanah dilakukan di Laboratorium Ilmu Tanah Fakultas Pertanian Universitas Udayana.

Alat dan bahan yang digunakan dalam penelitian ini adalah Kon Tiki, ayakan berukuran $(0,25 \mathrm{~mm}, 2.00 \mathrm{~mm}, 2,38$ $\mathrm{mm}, 2,83 \mathrm{~mm}$ dan $3,36 \mathrm{~mm}$ ), polybag berukuran $30 \times 35 \mathrm{~cm}$, terai semai, penggaris,alat tulis, gelas ukur, tanah berpasir, pupuk urea, dan bambu, air, benih sawi hijau.

Penelitian ini menggunakan rancangan acak lengkap dengan pola factorial 2 faktor,faktor pertama adalah faktor ukuran biochar: B1= 0,25-2 $\mathrm{mm}$, $\mathrm{B} 2=2,38-2,83 \mathrm{~mm}, \mathrm{~B} 3=2,83-3,36 \mathrm{~mm}$ dan faktor kedua yaitu faktor dosis pupuk : $\mathrm{P} 0=$ tanpa pupuk, $\mathrm{P} 1=0,2 \mathrm{~g}, \mathrm{P} 2=0,4 \mathrm{~g}, \mathrm{P} 3=0,6$ g. Perlakuan ini diulang sebanyak 3 kali dengan jumlah unit yang diuji adalah 36 .

Penyemaian benih dilakukan pada tray semai dengan jumlah benih yang di semai sebanyak 80 benih, pembibitan sawi hijau dilakukan selama 14 hari, setelah pimbibitan selesai dilanjutkan memindahkan tanah ke polybag dan dicampur biochar sesuai dengan perlakuan yang diterapkan pemindahan tanaman dilakukan pada hari ke 15 dengan jumlah tanaman perpolybag sebanyak 2 tanaman, pemupukan dilakukan 2 minggu setelah tanaman dengan dosis yang sudah ditentukan dan pemeliharaan meliputu pemasangan paranet 2 minggu awal setelah tanam dan penyiraman dilakukan setiap hari dengan jumlah sesuai dengan kapasitas lapang tanah.

Pemanenan sawi hijau dilakukan setelah tanaman berumur 1 bulan setelah tanam. Pemanenan dilakukan dengan mencabut tanaman sampai akarnya, kemudian akar dibersikan dari sisa tanah dan tanaman di timbang terpisah dengan akar tanaman.

Parameter yang diukur dalam penelitian ini adalah kadarnitrat, ammonium, pH tanah, respirasi tanah, populasi mikroganisme, efesiensi pupuk dan hasil tanaman. Pengukuran hasil 


\section{ANAK AGUNG GDE PREHATRESNA ADI ASMARA et al. Pengaruh Ukuran Biochar...}

tanaman dilakukan dengan penimbangan

berat segar dan berat kering oven tanaman.

\section{HASIL DAN PEMBAHASAN}

Tabel 1. Pengaruh Pemberian Pupuk Urea dan Biochar Bambu terhadap Efesiensi Pupuk dan Hasil Tanaman Sawi Hijau

\begin{tabular}{|c|c|c|c|c|}
\hline \multirow{2}{*}{ No } & \multirow{2}{*}{ Parameter Pengamatan } & \multicolumn{3}{|c|}{ Perlakuan } \\
\hline & & $\mathrm{B}$ & $\mathrm{P}$ & $\mathrm{B} \times \mathrm{P}$ \\
\hline 1 & Kadar Amonium & ns & $* *$ & ns \\
\hline 2 & Kadar Nitrat & ns & $* *$ & ns \\
\hline 3 & Populasi Mikroba & $* *$ & $* *$ & $*$ \\
\hline 4 & Efisiensi Pupuk & ns & $*$ & ns \\
\hline 5 & Berat Segar Tanaman & ns & $* *$ & ns \\
\hline 6 & Berat Segar Akar & ns & ns & ns \\
\hline 7 & Berat Kering Tanaman & ns & ns & ns \\
\hline 8 & Berat Kering Akar & ns & ns & ns \\
\hline 9 & Respirasi & ns & $* *$ & ns \\
\hline 10 & $\mathrm{pH}$ & ns & ns & ns \\
\hline Keteran & $\begin{aligned} & * * \\
* & : \text { Berpengaruh sangat nyata } \\
& : \text { Berpengaruh nyata } \\
\text { ns } & : \text { Berpengaruh tidak nyata }\end{aligned}$ & & & \\
\hline
\end{tabular}

Hasil analisis statistik untuk berpengaruh sangat nyata terhadap populasi mengetahui signifikansi pengaruh pemberian pupuk urea dan biochar bambu terhadap efesiensi pupuk dan hasil tanaman sawi hijau disajikan pada Tabel 1. Hasil analisis menunjukan bahwa pemberian pupuk dalam Tabel 1 perlakuan $\mathrm{P}$ berpengaruh sangat nyata terhadap kadar ammonium nitrat, efesiensi pupuk, populasi mikroba, berat segar tanaman dan respirasi tanah namun berpengaruh tidak nyata terhadap $\mathrm{pH}$ tanah, berat segar akar, berat kering tanaman dan berat kering akar tanaman, pada Tabel 1 menunjukan pemberian perlakuan $\mathrm{B}$ biochar bambu mikroba serta berpengaruh nyata terhadap respirasi tanah, namun pemberian perlakuan biochar bambu berpengaruh tidak nyata pada kadar amonium dan nitrat, $\mathrm{pH}$ tanah, efesiensi pupuk, berat segar tanaman, berat segar akar, berat kering tanaman dan berat kering akar.

\section{Karakteristik Tanah dan Hasil Tanaman} Hasil uji laboratorium dan
pengukuran hasil tanaman terhadap parameter karakteristik tanah dari perlakuan penelitian disajikan pada Tabel 2 sampai Tabel 5. 
Agrotrop : Journal on Agriculture Science, 11 (2): 157 - 166 (2021)

Tabel 2. Pengaruh Biochar Bambu dan Pupuk Urea terhadap Sifat Kimia Tanah

\begin{tabular}{cccc}
\hline \multirow{2}{*}{ Perlakuan } & \multicolumn{3}{c}{ Variabel Pengamatan } \\
\cline { 2 - 4 } & $\begin{array}{c}\text { Kadar Amonium } \\
(\%)\end{array}$ & $\begin{array}{c}\text { Kadar Nitrat } \\
(\%)\end{array}$ & $\mathrm{pH}$ \\
\hline $\mathrm{B}_{1}$ & $4,38 \mathrm{a}$ & $2,68 \mathrm{a}$ & $7,20 \mathrm{a}$ \\
$\mathrm{B}_{2}$ & $4,28 \mathrm{a}$ & $2,83 \mathrm{a}$ & $7,12 \mathrm{a}$ \\
$\mathrm{B}_{3}$ & $5,16 \mathrm{a}$ & $2,95 \mathrm{a}$ & $7,13 \mathrm{a}$ \\
\hline $\mathrm{BNT} \mathrm{5 \%} 5$ & - & - \\
\hline $\mathrm{P}_{0}$ & $1,52 \mathrm{~b}$ & $1,00 \mathrm{~b}$ & $7,17 \mathrm{a}$ \\
$\mathrm{P}_{1}$ & $5,37 \mathrm{a}$ & $3,26 \mathrm{a}$ & $7,21 \mathrm{a}$ \\
$\mathrm{P}_{2}$ & $5,67 \mathrm{a}$ & $3,24 \mathrm{a}$ & $7,13 \mathrm{a}$ \\
$\mathrm{P}_{3}$ & $5,87 \mathrm{a}$ & $3,78 \mathrm{a}$ & $7,10 \mathrm{a}$ \\
\hline BNT 5\% & 1,56 & 1,00 & - \\
\hline
\end{tabular}

Data signifikansimenunjukkan bahwa terdapat interaksi yang tidak nyata antara pemberian biochar berukuran partikel dan pupuk urea dengan dosis yang sudah ditentukan. Pemberian biochar menunjukan pengaruh yang tidak nyata terhadap ammonium dan nitrat, pemberian urea menunjukan pengaruh sangat nyata terhadap kadar ammonium dan nitrat. Pada Tabel 4.2 menunjukkan bahwa pada faktor pemberian biochar dengan kadar amonium terbaik adalahB 3 yaitu $5,16 \%$ sedangkan pada data kadar nitrat pemberian biochardengan ukuran $\mathrm{B}_{3}$ memberikan hasil terbaik yaitu sebesar $0,41 \%$. Pada faktor pupuk urea, perlakuan dengan kandungan kadar ammonium terbaik pada perlakuan $\mathrm{P}_{2}$ yaitu sebesar $5,67 \%$ dan pada parameter kadar nitrat perlakuan dengan kandungan terbaik yaitu $\mathrm{P}_{3}$ sebesar 3,78\%. Kandungan pupuk urea masih terjerap didalam tanah karena tingkatan $\mathrm{pH}$ tanah pada penelitian ini berada pada nilai 7 yang berarti netral, kemasaman tanah merupakan salah satu sifat yang penting, sebab terdapat hubungan $\mathrm{pH}$ tanah dengan ketersediaan unsur hara didalam tanah, karena pada $\mathrm{pH}$ tanah yang masam banyak ditemukan unsur hara yang bersifat racun dan sebagai pengikat unsur hara sehingga unsur hara tidak dapat diserap oleh tanaman dan pada $\mathrm{pH}$ tanah yang netral unsur hara akan lebih mudah larut dan lebih mudah diserap oleh tanaman (Hardjowigeno, 2007). Hasil analisis statistika menunjukkan bahwa pemberian biochar bambu dan pupuk urea menunjukkan bahwa tingkat keaasaman tanah tertingi pada perlakuan $\mathrm{P}_{1}$ pemberian pupuk urea $100 \mathrm{~kg} / \mathrm{ha}$ dengan nilai sebesar 7,21 dan terendah pada perlakuan $\mathrm{P}_{3}$ sebesar 7,1. Pada perlakuan faktor B pemberian biochar berukuran $\mathrm{B}_{1}$ 


\section{ANAK AGUNG GDE PREHATRESNA ADI ASMARA et al. Pengaruh Ukuran Biochar...}

menunjukkan tingkat keasaman tanah tanah dalam penelitian ini masuk kedalam tertinggi yaitu sebesar 7,2. Tingkat $\mathrm{pH}$ tingkatan netral.

Tabel 3. Pengaruh Biochar Bambu dan Pupuk Urea terhadap Populasi Mikroba

\begin{tabular}{cccc}
\hline Perlakuan & $\mathrm{B}_{1}$ & $\mathrm{~B}_{2}$ & $\mathrm{~B}_{3}$ \\
\hline $\mathrm{P}_{0}$ & $8,94 \mathrm{a}$ & $8,26 \mathrm{a}$ & $8,08 \mathrm{a}$ \\
& $(\mathrm{A})$ & $(\mathrm{B})$ & $(\mathrm{B})$ \\
$\mathrm{P}_{1}$ & $54,71 \mathrm{a}$ & $34,39 \mathrm{~b}$ & $24,22 \mathrm{~b}$ \\
& $(\mathrm{~A})$ & $(\mathrm{A})$ & $(\mathrm{A})$ \\
$\mathrm{P}_{2}$ & $54,53 \mathrm{a}$ & $20,53 \mathrm{~b}$ & $17,10 \mathrm{~b}$ \\
& $(\mathrm{~A})$ & $(\mathrm{B})$ & $(\mathrm{A})$ \\
$\mathrm{P}_{3}$ & $39,33 \mathrm{a}$ & $40,29 \mathrm{a}$ & $24,69 \mathrm{a}$ \\
& $(\mathrm{A})$ & $(\mathrm{A})$ & $(\mathrm{A})$ \\
\hline Keterangan : & Huruf kecil dibaca arah vertikal, huruf kapital dibaca \\
& arah horizontal. Angka yang diikuti huruf - huruf yang \\
& sama menunjukkan beda tidak nyata berdasarkan uji \\
& BNT taraf 5\%.
\end{tabular}

Hasil analisis statistika menunjukan bahwa terdapat interaksi yang nyata antara pemberian biochar dan pupuk urea terhadap populasi mikroba. Pemberian biochar menunjukkan pengaruh yang sangat nyata terhadap populasi mikroba dan pemberian pupuk urea berpengaruh sangat nyata terhadap populasi mikroba yang dapat di lihat pada Tabel 4.3. Tingkat populasi mikroba dalam tanah terjadi peningkatan daripada control, hasil tertinggi terdapat pada perlakuan B1P1 sebesar 54,71 $10^{6} \mathrm{spk}$ $\mathrm{g}^{-1}$. Biochar bambu berukuran $0,25 \mathrm{~mm}$ $2 \mathrm{~mm}$ memiliki area permukaan yang lebih besar sehingga mikroba lebih mudah mengdegradasi partikel biochar yang lebih halus untuk memenuhi kebutuhan nutrisinya. Keasaman tanah sangat mempengaruhi perkembangan mikroba dalam tanah, pada tanah dengan $\mathrm{pH}$ 6-7 (netral) merupakan kondisi $\mathrm{pH}$ tanah yang baik untuk pengurai bahan organik hidup. Atmaja, (2017) menyatakan mikroorganisme yang terdapat di dalam tanah berperan dalam meningkatkan kesuburan tanah seperti proses pelapukan bahan organik dan pendauran unsur hara. 
Agrotrop : Journal on Agriculture Science, 11 (2): 157 - 166 (2021)

Tabel 4. Pengaruh Biochar Bambu dan pupuk Urea terhadap Respirasi Tanah

\begin{tabular}{cc}
\hline \multirow{2}{*}{ Perlakuan } & Variabel Pengamatan \\
\cline { 2 - 2 } & Respirasi $\left(\mathrm{mg} \mathrm{C}-\mathrm{CO}_{2} / \mathrm{g}\right.$ tanah/ $\left.\mathrm{minggu}\right)$ \\
\hline $\mathrm{B}_{1}$ & $2,30 \mathrm{a}$ \\
$\mathrm{B}_{2}$ & $2,05 \mathrm{a}$ \\
$\mathrm{B}_{3}$ & $1,85 \mathrm{~b}$ \\
\hline BNT 5\% & 0,34 \\
\hline $\mathrm{P}_{0}$ & $0,64 \mathrm{c}$ \\
$\mathrm{P}_{1}$ & $2,83 \mathrm{a}$ \\
$\mathrm{P}_{2}$ & $2,57 \mathrm{a}$ \\
$\mathrm{P}_{3}$ & $2,22 \mathrm{~b}$ \\
\hline BNT 5\% & 0,39 \\
\hline
\end{tabular}

Hasil analisis statistika menunjukkan bahwa terdapat interaksi yang tidak nyata antara pemberian biocharbambu dan pupukurea terhadap respirasi tanah. Pemberian biochar berpengaruh nyata terhadap respirasi tanah, pemberian dosis pupuk urea berpengaruh sangat nyata terhadap respirasi tanah. Respirasi tanah pada pemberian biochar berukuran partikel $\mathrm{B}_{1}$ mempunyai nilai tertinggi yaitu sebesar 2,30 $\mathrm{mg} \mathrm{C}-\mathrm{CO}_{2} / \mathrm{g}$ tanah/minggu atau lebih tinggi dibandingkan dengan perlakuan lainnya, sedangkan pada pemberian dosis pupuk urea perlakuan $\mathrm{P}_{1}$ menghasilkan nilai respirasi tanah tertinggi yaitu $2,83 \mathrm{mg} \mathrm{C}$ $\mathrm{CO}_{2} / \mathrm{g}$ tanah/ minggu seperti yang terlihat pada Tabel 4.4 tingginya respirasi pada pemberian biochar berukuran partikel $\mathrm{B}_{1}$ berkaitan dengan jumlahpopulasi mikroba pada Tabel 4.3 sama-sama paling tinggi, karena (kadar $\mathrm{CO}_{2}$ tanah) sangat dipengaruhi besarnya populasi mikroba.Peningkatan populasi mikroba akan diikuti oleh peningkatan kadar $\mathrm{CO}_{2}$ tanah, Lubna dan Simbiring, (2013) menyatakan dimana peningkatan populasi mikroba akan diikuti oleh peningkatan kadar $\mathrm{CO}_{2}$ tanah. 


\section{ANAK AGUNG GDE PREHATRESNA ADI ASMARA et al. Pengaruh Ukuran Biochar...}

Tabel 5. Pengaruh Biochar Bambu dan Pupuk Urea terhadap Hasil Tanaman dan Efisiensi Pupuk

\begin{tabular}{cccccc}
\hline \multirow{2}{*}{ Perlakuan } & \multicolumn{5}{c}{ Variabel Pengamatan } \\
\cline { 2 - 6 } & $\begin{array}{c}\text { Berat Segar } \\
\text { Tanaman } \\
(\mathrm{g})\end{array}$ & $\begin{array}{c}\text { Berat Kering } \\
\text { Tanaman } \\
(\mathrm{g})\end{array}$ & $\begin{array}{c}\text { Berat Segar } \\
\text { Akar } \\
(\mathrm{g})\end{array}$ & $\begin{array}{c}\text { Berat } \\
\text { Kering } \\
\text { Akar }(\mathrm{g})\end{array}$ & $\begin{array}{c}\text { Efisiensi } \\
\text { Pupuk }\end{array}$ \\
\hline $\mathrm{B}_{1}$ & $138,16 \mathrm{a}$ & $11,49 \mathrm{a}$ & $10,93 \mathrm{a}$ & $1,11 \mathrm{a}$ & $5,38 \mathrm{a}$ \\
$\mathrm{B}_{2}$ & $133,63 \mathrm{a}$ & $11,34 \mathrm{a}$ & $10,48 \mathrm{a}$ & $1,08 \mathrm{a}$ & $4,12 \mathrm{a}$ \\
$\mathrm{B}_{3}$ & $142,13 \mathrm{a}$ & $10,57 \mathrm{a}$ & $10,26 \mathrm{a}$ & $1,04 \mathrm{a}$ & $3,08 \mathrm{a}$ \\
\hline $\mathrm{BNT}_{5 \%}$ & - & - & - & - & $\mathrm{ns}$ \\
\hline $\mathrm{P}_{0}$ & $77,63 \mathrm{~b}$ & $10,76 \mathrm{a}$ & $11,09 \mathrm{a}$ & $1,17 \mathrm{a}$ & $0,17 \mathrm{a}$ \\
$\mathrm{P}_{1}$ & $163,81 \mathrm{a}$ & $10,54 \mathrm{a}$ & $9,39 \mathrm{a}$ & $0,97 \mathrm{a}$ & $5,66 \mathrm{~b}$ \\
$\mathrm{P}_{2}$ & $165,79 \mathrm{a}$ & $11,91 \mathrm{a}$ & $10,97 \mathrm{a}$ & $1,14 \mathrm{a}$ & $6,60 \mathrm{a}$ \\
$\mathrm{P}_{3}$ & $144,66 \mathrm{a}$ & $11,31 \mathrm{a}$ & $10,78 \mathrm{a}$ & $1,04 \mathrm{a}$ & $4,33 \mathrm{a}$ \\
\hline BNT 5\% & 36,60 & - & - & - & 4,09 \\
\hline
\end{tabular}

Hasil analisis berat segar tanaman dan berat kering tanaman pada Tabel 4.5 menunjukkan pada perlakuan $\mathrm{B}$ hasil berat segar tanaman tertinggi pada perlakuan $\mathrm{B}_{3}$ $142,13 \mathrm{~g}$ dan pada perlakuan $\mathrm{P}$ berat segar tanaman tertinggi yaitu pada perlakuan $\mathrm{P}_{2}$ 165,79 g. pada perlakuan B hasil berat kering tnaman tertinggi pada $\mathrm{B}_{1}$ sebesar $11,49 \mathrm{~g}$ dan pada perlakuan $\mathrm{P}$ hasil berat kering tertinggi pada $\mathrm{P}_{2}$ sebesar 11,91 g. Hasil analisis menunjukkan bahwa berat segar akar tanaman tertinggi pada perlakuan $\mathrm{P}_{0}$ sebesar 11,91 g, pada perlakuan faktor B berat kering oven tanaman tertinggi pada pemberian biochar berukuran $\mathrm{B}_{1}$ sebesar $10,93 \mathrm{~g}$. bahwa berat kering akar tertinggi pada perlakuan $\mathrm{P}_{0}$ tanpa pupuk dengan nilai sebesar 1,17 g, pada perlakuan faktor B berat kering oven akar tanaman tertinggi pada pemberian biochar berukuran $\mathrm{B}_{1}$ sebesar 1,11g. Menurut Liescahyani dkk., 2014 biochar dapat memperbaiki sifat tanah tempat tumbuh tanaman sehingga akar tanaman juga mampu tumbuh dan berkembang, pemberian biochar mampu memperbaiki sifat fisika tanah yang mendukung pertumbuhan akar yaitu penurunan berat volume tanah dan peningkatan jumlah ruang pori total yang menyebabkan akar tanaman mampu tumbuh dan berkembang dengan baik. Hasil analisis efisiensi pupuk dalam penelitian ini menghasilkan bahwa pada faktor $\mathrm{P}$ perlakuan $\mathrm{P}_{2}$ yaitu pemberian pupuk urea dengan dosis $200 \mathrm{~kg} / \mathrm{ha}$ menghasilkan nilai tertinggi sebesar $6,60 \%$ dan pada faktor B perlakuan $\mathrm{B}_{1}$ menghasilkan nilai efisiensi pupuk tertinggi yaitu sebesar 5,38\%. Efisiensi pupuk dipengaruhi oleh $\mathrm{pH}$ tanah yang netral sehingga akar tanaman dapat 
menyerap unsur hara dengan maksimal. $\mathrm{pH}$ yang netral dan tekstur tanah yang berpasir memberikan kemampuan akar hidup dan berkembang lebih besar sehingga dapat memaksimalkan penyerapan unsur hara. Hal ini didukung oleh penelitian Triono dkk., 2013 yang menyatakan bahwa efisiensi pupuk $\mathrm{N}$ dipengaruhi oleh respon tanaman terhadap pemberian pupuk tunggal atau manjemuk yang berkaitan dengan produktivitas tanaman.

\section{SIMPULAN}

Berdasarkan hasil penelitian dan pembahasan yang diuraikan, maka dapat disimpulkan bahwa hasil tanaman menunjukan hasil yang berbeda tidak nyata disetiap pelakuan, hasil tanaman tertinggi terdapat pada pemberian dosis urea $200 \mathrm{~kg}$ ha $^{-1}$ sebesar 165,79 g. Hasil tanaman tertinggi pada pemberian biochar berukuran 2,83- $3,36 \mathrm{~mm}$ sebesar 142,13 g. Nilai efisiensi tertinggi terdapat pada pemberian dosis urea $200 \mathrm{~kg} \mathrm{ha}^{-1}$ yaitu sebesar $6,60 \%$. Nilai efisiensi tertinggi pada pemberian biocharbamboo terdapat pada biochar berukuran0,25 mm-2,00 mm yaitu sebesar $5,38 \%$ berbeda tidak nyata dengan perlakuan lainnya.

\section{DAFTAR PUSTAKA}

Anggraini, D. (2020). Respon Pertumbuhan dan Hasil Tanaman Sawi Pakcoy Hijau (Brassica rapa L.) Akibat Pemberian Pupuk Organik Cair (POC) Urin Sapi di Polybag. Universitas Tridinanti Palembang.

Atmaja, I. W. D. (2017). Kajian Sifat Biologi Tanah Pada Beberapa Tipe penggunaan Lahan. Universitas Udayana.

Gani A. (2009). Biochar Penyelamat Lingkungan. Warta Penelitian dan Pengembangan Pertanian Vol. 31: 6.

Hardjowigeno, S. (2007). Ilmu Tanah. Penerbit Pusaka Utama, Jakarta.

Ibrahim, Y., \& Tanaiyo, R. (2018). Respon Tanaman Sawi (Brassica juncea L.) terhadap Pemberian Pupuk Organik Cair (POC) Kulit Pisang dan Bonggol Pisang. Jurnal Agropolitan, 5(1):6369.

Istarofah, \& Salamah, Z. (2017). Pertumbuhan Tanaman Sawi Hijau (Brassica juncea L.) dengan Pemberian Kompos Berbahan Dasar Daun Paitan (Thitonia diversifolia). Bio-Site, 3(1).

Liescahyani, I., Djatmiko H., \& Sulistyaningsih, N. (2014). Pengaruh Kombinasi Bahan Baku dan Ukuran Partikel Biochar terhadap Perubahan Sifat Fisika pada Tanah Pasiran. Berkala Ilmiah Pertanian, 1(1).

Lubna, D., \& Sembiring, E. (2013). Emisi $\mathrm{CO}_{2}$ dan Penurunan Karbon Organik pada Campuran Tanah dan Kompos (Skala Laboratorium). Teknik Lingkungan, 19(1): 23-33.

Nigussie, A., Kissi, E., Misganaw, M., \& Ambaw, G. (2012). Effect of Biochar Application on Soil Properties and Nutrient untake of lettuces (Lactuca sativa) Grown in Chromium Polluted Soils. American-Eurasian J. Agric \& Environ.Sci.,12(3):369-376. 
ANAK AGUNG GDE PREHATRESNA ADI ASMARA et al. Pengaruh Ukuran Biochar...

Pracaya. (2011). Bertanam Sayur Organik.

Penebar Swadaya. Jakarta 123

(Diakses tanggal 21 Desember 2019).

Rahmadani, R. H., Roviq, M., \& Maghfoer,

M. D. (2016). Pengaruh Sumber

Pupuk Nitrogen dan Waktu

Pemberian Urea pada Pertumbuhan

dan Hasil Tanaman Jagung Manis

(Zea mays Sturt. Var. saccharata).

Jurnal Produksi Tanaman, 4(1):8-15.

Triyono, A., Purwanto, \& Budiyono.

(2013). Efisiensi Penggunaan Pupuk -

$\mathrm{N}$ untuk Pengurangan Kehilangan

Nitrat pada Lahan Pertanian.

Prosiding Seminar Nasional

Pengelolaan Sumber Daya Alam dan

Lingkungan, 1(2). 